\title{
Embryo culture media for human IVF: which possibilities exist?
}

\author{
Insan IVF ‘ için embriyo kültür ortamı: hangi olasılıklar mevcut? \\ Irmhild Gruber, Matthias Klein \\ Department of Gynecology and Obstetrics, Landesklinikum St. Poelten, St. Poelten, Austria
}

\section{Abstract}

The last three decades have seen considerable progress in the development of culture media for ART and infertility treatment. Basic research on the metabolism of mammalian preimplantation embryos demonstrated the specific needs in the evolving stage of the embryo growing in vitro. Two different philosophies led to two different culture strategies for human preimplantation embryos: the 'back-to-nature' or sequential culture principle, and 'let-the-embryo-choose' or one-step culture principle. Both systems are commercially available and the discussion between the different groups of scientists is ongoing. As a matter of fact, all ART culture media currently used are not optimal for the growing human preimplantation embryo. However, further research is needed to reduce stress to the human preimplantation embryo and determine how many embryos from a treatment cycle are capable of producing a live birth.

(J Turkish-German Gynecol Assoc 2011; 12: 110-7)

Key words: Culture media, back-to-nature, 'let-the-embryo-choose', media components

Received: 17 March, 2011

Accepted: 22 April, 2011
Özet

Son 3 yllda ART ve infertilite tedavisi için kültür ortamı geliştirilmesinde önemli ilerlemeler görülmektedir. İmplantasyon öncesi memeli embriyosu metabolizması üzerine temel araştırma, in vitro gelişen embriyonun gelişim aşamalarındaki özgün gereksinimlerini gösterdi. İki farklı düşünce şekli implantasyon öncesi insan embriyolanı için iki farklı kültür stratejisine yol açtı: 'doğaya dönüş' veya ardışık kültür ilkesi ve 'bırak embriyo seçsin' veya tek-adım kültür ilkesi. Her iki sistem de ticari olarak mevcuttur ve farklı gruplardaki bilim adamları arasındaki tartışma devam etmektedir. Gerçekte, şu an kullanımda olan ART kültür ortamlarının hiç biri implantasyon öncesi insan embriyoları için optimum değildir. Bununla beraber, implantasyon öncesi insan embriyosuna stresi azaltmak ve bir tedavi döngüsünden elde edilen embriyoların kaç tanesinin canlı bir doğum oluşturma becerisine sahip olduğunu belirlemek için daha fazla araştırmaya gerek vardır. (J Turkish-German Gynecol Assoc 2011; 12: 110-7)

Anahtar kelimeler: Kültür ortamı, 'doğaya dönüş', 'bırak embriyo seçsin', besiyeri bileşenleri

Geliş Tarihi: 17 Mart 2011

Kabul Tarihi: 22 Nisan 2011

\section{Introduction}

The goal of embryo culture in an assisted reproductive (ART) programme is to improve the quality of embryos developing in the laboratory and the chances of successful delivery of a healthy baby. Culture conditions for human embryos have evolved over the past thirty years (1-4).

Cleaving embryos normally develop in the fallopian tube, whereas the natural environment for morulae and blastocysts is the uterine cavity. Previously, it was conventional to use media permitting culture of human in-vitro fertilized embryos for 2 to 3 days to reach the four-to-eight cell stage, with additional embryo transfer to the patient (5). Premature replacement of the human embryo to the uterus may in part account for the low implantation rates associated with human IVF, with only approximately $10 \%$ of embryos transferred leading to a live birth. Further basic research on the metabolism of invitro fertilized embryos revealed that there are specific needs, depending on the developmental stage of the preimplantation embryo. In addition, improvements in culture media resulted from an increased understanding of the environment of the oviduct and uterus (6-8). Since 1997, the extended culture in sequential serum-free culture media has attracted more attention. The ability to culture zygotes to the blastocyst stage should help to synchronize the embryo with the female reproductive tract, and to help to identify those embryos with little development potential (3).

\section{Evolution of embryo culture media}

The idea introduced by Bernard in the late 1800s that the immediate environment surrounding living tissues is an active one led, in turn, to the notion that organs and tissues could be studied outside their setting in a suitable fluid formulated to facilitate these studies (9). Less than 10 years later, Ringer devised a solution of salts still used today in surgical treatments. It is an interesting aspect that the culture media evolved and used in the clinical setting were construed to support the development of somatic cell culture applications. The first success of fertilization of the human oocyte in vitro by Robert Edwards was accomplished in a simple, chemically defined media. These commercially available media were a modified Earle's balanced salt solution, and a modified Ham's 
F10 or T6. They were supplemented with maternal serum thus converting them into biological media $(10,11)$. Menezo et al. (12) broke with the tradition of using balanced salt solution and produced a medium containing amino acids without the need of a serum supplement. Another medium specifically designed for human IVF was human tubal fluid (HTF) (13). Human tubal fluid, supplemented with either whole serum or with serum albumin, gained great popularity for the use of day 2 or day 3 human embryo cultures, and has remained in use ever since. A culture medium is a foreign environment for the human embryo. Hence, the design of media is complicated, because the components must be selected, and their concentrations determined in order to minimize stress for the cultured embryo $(2,14,15)$. It also became clear that early embryos show an evolving need for energy substrates, moving from a pyruvatelactate preference - while the embryos are under maternal genetic control - to glucose-based metabolism after activation of the embryonic genome $(7,16)$. Two investigators responded to these findings by modifying the HTF media. Quinn (17) removed glucose and inorganic phosphate, QB 11, for obtaining the first glucose-free medium. Pool (18) also generated a HTF variant, called Preimplantation Stage 1 or P-1 medium, a glucose- and phosphate-free medium, but additionally containing the amino acid taurine. The improved understanding of both the physiological changes in oviduct and uterus (7) and the different metabolic needs of the cleavage-stage and blastocyst-stage embryo led to the development of stagespecific or "sequential" complex media G1/G2 (3). Barnes et al. (19) used this combination to produce pregnancy and live birth after the transfer of a single viable human blastocyst, and the media were first slightly modified and marked as the GIII/ G5 series of media. Other popular sequential systems, such as Quinn's series in the United States and the MediCult/Origio media from Europe and Cook from Australia, are also in widespread use. Lawitts and Biggers $(20,21)$ broke new ground to design a chemically defined media. They applied the principle of simplex optimization to determine the optimal concentration of each media component. This resulted in the formulation of Simplex Optimizition Medium (SOM). SOM has been modified in several ways to $\mathrm{mKSOM}^{\mathrm{AA}}$. Henceforth, it is possible to provide a one-step protocol (so-called global medium) to culture human zygotes to the blastocyst stage $(2,5)$. Now, there exist three commercially available one-step human embryo culture media (global ${ }^{\circledR}$, LifeGlobal, U.S.; Gynemed GM501 ${ }^{\circledR}$, Lensahn, Germany; $\mathrm{SSM}^{\mathrm{TM}}$, Irvine Scientific, U.S.). At least nine companies now advertise media for the culture of human preimplantation embryos to the blastocyst stage (Table 1).

The recovery of immature oocytes followed by in-vitro maturation (IVM) of these oocytes led to the development of specific conventional available IVM culture media.

Two philosophies for human embryo culture media

The design of media for the culture of preimplantation embryos has been influenced by two fundamentally different philosophies $(2,22)$. However, growth of ART embryos is inferior to that of in vivo embryos, indicating that ART procedures invoke cellular and metabolic stress situations and the ART embryo is forced to spend energy to adapt to this foreign environment. In particular, the culture media is an important factor in successful in vitro interactions between gametes and subsequent embryo development (3). Manufacturers of human embryo culture media follow either the "back-to-nature" (sequential media) or the "let-the-embryo-choose" (global media) philosophy (23). The key components of both modern media are shown in Table 2.

\section{The sequential culture-"back-to-nature" principle}

The "back-to-nature" attempts to mimic the changing needs of the developing zygote and embryo in a media should approximate the concentration to which the embryo is naturally exposed $(3,23)$. The embryo is capable of actively controlling ionic gradients etc, and is able to regulate its internal environment. Therefore, with regard to embryo physiology, it is appropriate to consider the preimplantation period in at least two phases: pre- and post-compaction (3). Such a breakdown of the preimplantation period is of importance when one considers changes to medium formulations. Other considerations include the time at which the embryonic genome is activated (3).

\section{The monoculture "let-the-embryo-choose" principle}

The design of a culture medium involves the simultaneous use of all the concentrations in a mixture because the effects of each component in the medium may depend on the concentrations of the other components (23). As long as concentrations are within 'tolerable ranges', the embryo itself will adapt and utilize whatever it requires $(2,23,24)$. This philosophy led to a family of media in which all of the substances necessary to early embryological development are provided, and there is no need for a media change. One-step formulation is applied throughout the entire in-vitro development from fertilization to the blastocyst stage of the embryo.

Four protocols can be used for the culture from fertilization to the blastocyst stage in an ART laboratory: [a] sequential media protocol, with an interrupted culture where two media of different compositions are used sequentially, change of medium occurs on day 3 of embryo culture, [b] sequential media protocol with fresh medium change every day, [c] monoculture, uninterrupted culture using one medium throughout the 5 days of embryo culture, [d] interrupted culture where a monoculture medium is used throughout but is renewed on day 3 of embryo culture.

\section{Key components of ART culture media}

Studies using the development of mammalian preimplantation embryos in-vitro have played a major role in the understanding of pre-embryo physiology (for reviews, see 3, 24-30). As a result, this is also the limitation in the development of culture media for the human embryo. The most widely used models for the human embryo have been the mouse and the cow.

\section{Carbohydrates}

In brief, the early embryo shows a rather simplistic physiology and maintains only low levels of oxidative metabolism, whereas it exhibits a somatic-cell like physiology after compaction 
Table 1. Available commercial systems for human IVF culture

\begin{tabular}{|c|c|c|c|}
\hline \multicolumn{4}{|c|}{ One media system } \\
\hline Company & Medium & Culture period & Website \\
\hline LifeGlobal & global $^{\circledR}$ & day-1 to day-5/6 & www.lifeglobal.com \\
\hline Gynemed & GM501 & day-0 to day- $5 / 6$ & www.gynemed.de \\
\hline IrvineScientific & $\mathrm{SSM}^{\mathrm{TM}}$ & day- 0 to day-5/6 & www.irvinesci.com \\
\hline \multicolumn{4}{|c|}{ Sequential media system } \\
\hline Company & Medium & Culture period & Website \\
\hline \multirow[t]{2}{*}{ Cook Medical } & Cleavage & day-1 to day-3 & \multirow[t]{2}{*}{ www.cookmedical.com } \\
\hline & Blastocyst & day-3 to day-5/6 & \\
\hline \multirow[t]{2}{*}{ CooperSurgical } & Quinns Advantage ${ }^{\circledR}$ Cleavage & day-1 to day-3 & \multirow[t]{2}{*}{ www.coopersurgical.com } \\
\hline & Quinns Advantage ${ }^{\circledR}$ Blastocyst & day-3 to day- $5 / 6$ & \\
\hline \multirow[t]{2}{*}{ FertiPro } & FERTICULT $^{\mathrm{TM}}$ IVF Medium & day-1 to day-2 & \multirow[t]{2}{*}{ www.fertipro.com } \\
\hline & FERTICULT $^{\mathrm{TM}}$ G3 Medium & day-3 to day- 4 & \\
\hline \multirow[t]{2}{*}{ InVitroCare } & IVC-TWO $^{\mathrm{TM}}$ & day-0 to day-3 & \multirow[t]{2}{*}{ www.invitrocare.com } \\
\hline & IVC-THREE $^{\mathrm{TM}}$ & day-3 to day-5 & \\
\hline \multirow[t]{2}{*}{ Irvine Scientific } & $\mathrm{ECM}^{\circledR}$ & day- 0 to day-3 & \multirow[t]{2}{*}{ www.irvinesci.com } \\
\hline & MultiBlast $^{\circledR}$ & day-3 to day-5 & \\
\hline \multirow[t]{4}{*}{ Origio } & EmbryoAssist $^{\mathrm{TM}}$ & day- 0 to day- 3 & \multirow[t]{4}{*}{ www.origio.com } \\
\hline & BlastAssist $^{\mathrm{TM}}$ & day-3 to day-5 & \\
\hline & ISM1 & day-0 to day-3 & \\
\hline & ISM2 & day-3 to day-5 & \\
\hline \multirow[t]{4}{*}{ Vitrolife } & G- $1^{\mathrm{TM}}$ PLUS & day-1 to day-3 & \multirow[t]{4}{*}{ www.vitrolife.com } \\
\hline & G- $2^{\mathrm{TM}}$ PLUS & day-3 to day-5 & \\
\hline & $\mathrm{IVF}^{\mathrm{TM}}$ & day- 0 to day- 3 & \\
\hline & $\mathrm{CCM}^{\mathrm{TM}}$ & day-3 to day-5 & \\
\hline
\end{tabular}

utilizing a wider spectrum of nutrients, biosynthetic rates are increasing, along with an increased respiratory capacity and an ability to utilize glucose $(8,28)$. This involves a shift in the energy requirements at the time at which the embryonic genome is activated or at the post-compaction stage. Zygotes and subsequent cleavage stages prefer pyruvate as the primary source of energy, while the eight-cell-stage embryo uses glucose (31-33). Glucose is a key anabolic precursor and is required for the synthesis of triacylglycerols and phospholipids, and as a precursor for complex sugars and glycoproteins. Glucose also metabolized by the pentose phosphate pathway (PPP) generates ribose moieties required for nucleic acid synthesis (34).

\section{Amino acids}

It has been proposed that "amino acids-(AA)", a term which includes all 20 common and naturally occurring amino acids, are important regulators of mammalian preimplantation development (for reviews, see 8, 29, 35). Prior to embryonic genome expression, the embryo utilizes carboxylic acids and AA as energy sources (29). In addition, certain AA are known to function as biosynthetic precursor molecules (36), osmolytes (37), buffers of internal pH (38), antioxidants (39) and chelators, especially for heavy metals (40). It is important to note that there are also specific changes in the nitrogen requirements of the embryo $(27,28)$. The seven non-essential AA and glutamine stimulate the growth of the early cleavage embryo (41). In contrast, an inhibitory effect was seen on blastocyst development and viability if the thirteen essential AAs are presented at an early stage (42). At the post-compaction stage, both groups of AAs act stimulatory to the inner cell mass of blastocysts, while the non-essential AAs and glutamine lead to stimulation of the throphectoderm and hatching from the zona pellucida $(43,44)$. Leese at al. (45-47) have described AA turnover studies on the mammalian embryo and argued for "quiet" embryo metabolism during preimplantation embryo culture and development to produce the most viable embryos.

However, AAs in culture media also spontaneously undergo breakdown to release ammonium into the culture medium with concentration being time dependent. Ammonium is toxic to the embryo and reduces viability (48). Especially L-glutamine (Gln) is highly unstable in solution, where it breaks down fairly rapidly into equimolecular amounts of ammonium and pyrrolidine-5-carboxylic acid (for review see, 49). Therefore, Lane and Gardner (42) introduced a two-step (sequential) cul- 
Table 2. Key components of modern media

\begin{tabular}{|c|c|c|c|}
\hline Components & $\begin{array}{l}\text { One media system } \\
\text { Gynemed GM501 }^{\circledR}\end{array}$ & $\begin{array}{l}\text { Sequential media } \\
\text { G-1 }{ }^{\mathrm{TM}} \text { PLUS }\end{array}$ & $\begin{array}{c}\text { Sequential media } \\
\text { G-2 }{ }^{\mathrm{TM}} \text { PLUS }\end{array}$ \\
\hline \multirow[t]{6}{*}{ Salts } & Sodium chloride & Sodium chloride & Sodium chloride \\
\hline & Potassium chloride & Potassium chloride & Potassium chloride \\
\hline & Calcium chloride & Calcium chloride & Calcium chloride \\
\hline & Monopotassium phosphate & Sodium citrate & Sodium citrate \\
\hline & Magnesium sulphate & Magnesium sulphate & Magnesium sulphate \\
\hline & & Sodium dihydrogen phosphate & Sodium dihydrogen phosphate \\
\hline Buffer & Sodium bicarbonat & Sodium bicarbonate & Sodium bicarbonate \\
\hline \multirow[t]{3}{*}{ Energy Substrates } & Glucose & Glucose & Glucose \\
\hline & Sodium lactate & Sodium lactate & Sodium lactate \\
\hline & Sodium pyruvate & Sodium pyruvate & Sodium pyruvate \\
\hline Non-Essential AA's & NEAA's & 8 NEAA's & 9 NEAA's \\
\hline Glutamine Dipeptide & Alanyl-Glutamine & & \\
\hline Essential AA's & EAA's & 2 EAA's & 11 EAA's \\
\hline Chelator & EDTA & EDTA & none \\
\hline Macromolecules & none & Hyaluronan, HSA & Hyaluronan, HSA \\
\hline Fatty acid & none & Lipoic acid & none \\
\hline Vitamins & none & none & 4 Vitamins \\
\hline Indicator & Phenol Red optional & none & none \\
\hline Antibiotic & Gentamicin & Gentamicin & Genamicin \\
\hline Water & yes & yes & yes \\
\hline
\end{tabular}

ture media protocol to remove the accumulated ammonium. Another possibility is replacing Gln with a stable dipeptide of Gln (24). It must be noted that culture media should include sufficient levels of sulphur containing amino acids to minimize apoptosis leading to monozygote twinning (50).

\section{EDTA (Ethylenediaminetetraacetic acid)}

Its usefulness is based on its role as a ligand and chelating agent, i.e. its ability to "sequester" metal ions. After being bound by EDTA, metal ions remain in solution but exhibit diminished reactivity. The addition of EDTA to culture media alleviates the 2-cell block in mice embryos (51) and inhibits premature utilization of glycolysis by cleavage stage embryos, thereby preventing any Crabtree-like effect that is associated with arrest in culture (48). However, EDTA at a concentration of $0.1 \mathrm{mmol} / \mathrm{L}$ reduces blastocyst development and cell number (52). Other investigators indicated that an EDTA concentration of $0.005-0.01 \mathrm{mmol} / \mathrm{L}$ did not have a deleterious effect on murine preimplantation or postimplantation development (53).

\section{Regulation of cell volume-osmolytes}

Maintenance of a constant volume in the face of extracellular and intracellular osmotic perturbations is a critical problem faced by all cells. Most cells respond to swelling or shrinkage by activating specific metabolic or membrane-transport processes that return cell volume to its normal resting state. These processes are essential for the normal function and survival of cells (54). The osmotic pressure of oviduct fluid is $>360 \mathrm{mOsmol}$ (55). However, the osmolarity of most commercially available ART culture media is lower-at about 250-300 mOsmol. When the $\mathrm{NaCl}$ concentration is forced up to $290 \mathrm{mOsmol}$, the development of the embryo is severely impaired (56). Addition of extracellular AA, such as glycine, betaine, proline, alanine and hypotaurin which act as organic osmolytes, protects the preimplantation embryo against hypertonicity and increases embryo development $(37,56,57)$

\section{Impact of $\mathrm{pH}$ and buffers}

The $\mathrm{pH}$ only refers to hydrogen ion concentration and is only meaningful when applied to aqueous (water-based) solutions. When water dissociates it yields a hydrogen ion and a hydroxide ion, $\mathrm{H}_{2} \mathrm{O}<-->\mathrm{H}^{+}+\mathrm{OH}^{-}$(for review see, 58, 59). It must be noted that $\mathrm{pH}$ is dynamic. The balance of $\mathrm{pH}$ depends on the association or dissociation of compounds. The most important ions are sodium, potassium, magnesium, chloride and lactate and also the AA glycine which acts as an intracellular zwitterionic buffer (60). An acceptable $\mathrm{pH}$ range for embryo culture media may be set between $\mathrm{pH} 7.4$ and 7.2. Culture media $\mathrm{pH}$ is regulated by the balance of $\mathrm{CO}_{2}$ concentration, supplied by the media and by the concentration of bicarbonate in the media. However, the intracellular 
$\mathrm{pH}$ in human cleavage embryonic cells is $\mathrm{pH}=7.2(61)$ and $\mathrm{pH}$ is an important cellular function which is necessary to maintain intracellular homeostasis. Moreover, after the compaction stage the preimplantation embryos appear to have more control over their intracellular $\mathrm{pH}$, because of the formation of tight junctions between cells $(38,62)$. Hence, there is a trend to culture cleavage stage embryos in a slightly lower $\mathrm{pH}$ and morulae and blastocysts in a slightly higher $\mathrm{pH}$ (low-high paradigm). Table 3 provides information about the recommended $\mathrm{pH}$ of commercial available media.

In the past, handling media were used with phosphate-buffered saline solutions (PBS) or different "Good's" buffers (63). Nowadays, especially two "Good's" puffers are used in commercially IVF handling media. The most commonly used buffer is 4-(2-hydroxyethyl)-1-piperazineethanesulphonic acid (HEPES at $21 \mathrm{mmol} / \mathrm{L}$ ), whereas some companies include 3-(N-morpholino)-propanesulphonic acid (MOPS). Both buffers have a $\mathrm{pK}_{\mathrm{a}}$ value of 7.2 , it is the closest of the zwitterionic buffers to the $\mathrm{pH}_{\mathrm{i}}$ of embryos of 7.12 .

Although both buffers have been widely used in IVF handling, studies indicated there may be species specific sensitivities to HEPES $(64,65)$. Results demonstrated that, in the presence of optimal culture conditions, such as $\mathrm{pH}$, gas concentration, osmolarity etc., HEPES is able to support mammalian embryo development and can also act as a chelator of heavy metals such as copper (66). If using MOPS for IVF handling at $37^{\circ} \mathrm{C}$ the $\mathrm{pK}_{\mathrm{a}}$ for this buffer is actually 7.02 (59), which is low, because most IVF laboratories target their media $\mathrm{pH}$ at 7.3. Yet, MOPS can interact with DNA in cellular preparations (67). Currently, it has not yet been defined whether both buffers used have an impact on embryo osmotic regulation (59).

\section{Macromolecules}

Common sources for macromolecules are proteins for culture media such as human serum albumin or synthetic serum. Both are added at concentrations of 5 to $20 \%$. Today, most commercial media include synthetic serum in which the composition is well known. Protein in the form of albumin is thought to maintain the stability of cell membranes and chelate trace amounts of toxic components presented in culture water, media components and culture dishes. Other functions include capillary membrane permeability and osmoregulation. The presence of macromolecules in embryo culture media serves to facilitate manipulation of gametes and embryos (8). However, the uses of any blood products involve the risk of potential contamination and infection of preimplantation embryos.

Some investigators have used synthetic polymers such as polyvinyl alcohol (PVA) and polyvinyl pyrrolidone (PVP) in ART (29) but neither can be considered a physiological alternative to protein (68).

Another physiological alternative to albumin is the glycosaminoglycan hyaluronate (also called hyaluronic acid or hyaluronan). The human embryo expresses the receptor for it throughout preimplantation development (69). While hyaluronate could not only replace serum albumin in culture, it increased the implantation rate of resultant mouse embryo blastocysts (70). Therefore, hyaluronate can replace albumin as a sole macro-
Table 3. Recommended pH-ranges of IVF culture media (adapted from Swain, 2010)

\begin{tabular}{|c|c|c|}
\hline Company & Medium & pH-range \\
\hline LifeGlobal & global ${ }^{\circledR}$ & $7.2-7.4$ \\
\hline Gynemed & GM501 & $7.2-7.4$ \\
\hline \multirow[t]{3}{*}{ Irvine Scientific } & $\mathrm{SSM}^{\mathrm{TM}}$ & $7.28-7.32$ \\
\hline & $\mathrm{ECM} \AA$ & $7.2-7.25$ \\
\hline & MultiBlast ${ }^{\circledR}$ & 7.3-7.4 \\
\hline \multirow[t]{2}{*}{ Cook Medical } & K-SICM & 7.3-7.5 \\
\hline & K-SICB & $7.3-7.5$ \\
\hline \multirow[t]{2}{*}{ Cooper Surgical } & Quinns Advantage ${ }^{\circledR}$ Cleavage & $7.1-7.3$ \\
\hline & Quinns Advantage ${ }^{\circledR B l a s t o c y s t ~}$ & $7.2-7.4$ \\
\hline \multirow[t]{2}{*}{ FertiPro } & FERTICULT $^{\mathrm{TM}}$ IVF Medium & $7.2-7.6$ \\
\hline & FERTICULT $^{\mathrm{rq}}$ G3 Medium & 7.3-7.6 \\
\hline \multirow[t]{2}{*}{ InVitroCare } & IVC-TWO $^{\mathrm{TM}}$ & $7.25-7.45$ \\
\hline & IVC-THREE $^{\mathrm{TM}}$ & $7.25-7.45$ \\
\hline \multirow[t]{4}{*}{ Origio } & EmbryoAssist $^{\mathrm{TM}}$ & 7.3-7.5 \\
\hline & BlastAssist $^{\mathrm{TM}}$ & 7.3-7.5 \\
\hline & ISM1 & $7.2-7.4$ \\
\hline & ISM2 & $7.2-7.4$ \\
\hline \multirow[t]{4}{*}{ Vitrolife } & G-1 ${ }^{\mathrm{TM}}$ PLUS & $7.27 \pm 0.07$ \\
\hline & G-2 ${ }^{\text {тм }}$ PLUS & $7.27 \pm 0.07$ \\
\hline & $\mathrm{IVF}^{\mathrm{TM}}$ & $7.35 \pm 0.10$ \\
\hline & $\mathrm{CCM}^{\mathrm{TM}}$ & $7.35 \pm 0.10$ \\
\hline
\end{tabular}

molecule in an embryo transfer medium and in some infertile patients it can improve ongoing pregnancy rates (71).

\section{Vitamins}

The addition of vitamins as antioxidants to the culture media containing glucose and phosphate helped to prevent a loss in respiration and metabolic control (72). The following possible vitamins are components of different ART culture media: ascorbic acid, cyanocobalamin, folic acid and tocopherol. Their optimum concentrations were determined using mouse zygote assays. Moderate dosages of vitamins $\mathrm{C}$ and $\mathrm{E}$ were seen to reduce oxidative damage in mouse embryo culture and improve their blastocyst development rate (73).

\section{Growth factors}

Mammalian embryos are naturally exposed to a complex mixture of growth factors that play a key role in growth and differentiation from the time of morula to blastocyst transition. However, defining their role and potential for improving in-vitro preimlantation development is complicated by factors such as gene expression of both the factors and their receptors. The blastocyst expresses ligands and receptors for several growth factors, many of which can cross-react thus making it difficult to interpret the effect of single factors added to a culture media $(74,75)$. 


\section{Antibiotics}

Embryo culture media are routinely supplemented with antibiotics to prevent bacterial contamination (76). Nowadays, commonly used antibiotics are penicillin ( $\beta$-lactam; $100 \mathrm{U} / \mathrm{ml})$, streptomycin (aminoglycoside; $100 \mu \mathrm{g} / \mathrm{ml}$ ) and gentamycin (aminoglycoside; $50 \mu \mathrm{g} / \mathrm{ml}$ ). The anti-bacterial effect of penicillin is attributed to its disturbance of cell wall integrity through the inhibition of the synthesis of peptidoglycan. Penicillin has no direct toxic effects on the preimplantation embryo. Streptomycin and gentamycin disturb bacterial protein synthesis. However, the aminoglycosides show more toxic effects (76).

\section{Literature review for comparison of media types}

A number of recent studies have been conducted to compare the effectiveness of commercially available ART culture media types. A search was conducted on published literature. Interestingly, most studies prefer 3-day human IVF embryo culture and embryo transfer for comparison of different media types (77-81). Differences in embryo quality were observed in studies that used modern formulated media versus standard media, but no differences in pregnancy rates were reported $(77,78)$. Moreover, no differences between a single or one-step defined medium versus a cleavage-stage media with regard to fertilization, pregnancy implantation rates, and ongoing pregnancy were found by following studies $(78,81)$. Ebert et al. (79) reported similar results. Only the rate of pregnancy losses was significantly lower in patients with the one-step medium GM501 as compared to the Universal IVF medium.

Three studies assess pregnancy outcomes and embryo morphology after transfer of day-3, day-5 or -6 embryos (82-84). Van Langendonckt et al. (82) matched two sequential media, G1.2/ G2.2 and Sydney IVF cleavage/blastocyst media. Both media yielded similar outcomes in the blastocyst transfer programme, but a lower day-3 embryo quality in the G1.2 media. The other two studies compared a single-step medium versus a sequential medium. Reed et al. (83) reported no significant difference for results on day-3 transfer. However, for day-5 transfer, a greater number of blastocysts were available from the single medium. Paternot et al. (84) described similar positive results using GM501.

Two other studies compared a single-step versus a sequential media system for the development of the human embryos to the blastocyst stage $(85,86)$. Biggers and Racowsky (85) found that significantly more IVF-embryos cultured in the single-step medium showed cytoplasmic pitting. IVF-blastocyst formation rates were not significantly different between the two media systems. Sepulveda et al. (86) referred to donor cycles, and had better development rates on days 3,4 and 5 as well as significantly higher implantation rates for embryos cultured in the single medium.

Furthermore, three other studies used the mouse model for comparison of commercially available media (53, 87, 88). Biggers and colleagues (53) observed no significant differences in the proportion of the blastocysts, rates of hatching, numbers of cells in the inner cell mass and trophectoderm between $\mathrm{KSOM}^{\mathrm{AA}}$ and G1.2/G2.2. However, Perin et al. (87) reported a higher blastocyst formation, higher cell numbers in the inner cell mass and higher hatching rates after culture in the singlestep medium $\mathrm{KSOM}^{\mathrm{AA}}$. Hentemann and Bertheussen (88) compared two sequential media, BlastAssist M1 and M2 versus G1/ $\mathrm{G} 2$, in a mouse model and achieved similar results.

\section{Concluding remarks}

In this review, two different types, 'back-to-nature' and 'let-theembryo-choose', of culture media were presented with the recent literature. Both media philosophies are part of worldwide practice in the ART laboratories. Based on recent literature, it can be concluded that global one step media are at least as useful as sequential media.

Human embryos can develop in vitro in rather different types of media from basic systems to sequential complex culture media. ART culture media contain only a subset of parts which are found under in vivo conditions. Hence, embryos cultured in-vitro was exposed to constant stress. Suboptimal culture conditions force the embryo to undergo adaptations, and thus lead to lower pregnancy and higher abortion rates.

It is evident that all necessary steps in ART as part of the treatment of infertility can influence the epigenetic programming during early development (89). Therefore, it is essential that a high level of quality control exists in the laboratory, and it is suggested that further investigations are necessary to optimize environmental conditions in which the preimplantation embryo can evolve.

\section{Conflict of interest}

No conflict of interest was declared by the authors.

\section{References}

1. Biggers JD. Pioneering mammalian embryo culture. In Bavister, B.D. (ed.). The Mammalian Preimplantation Embryo. Plenum Press, New York 1987; 1-22.

2. Bigger JD. Thoughts on embryo culture conditions. Reprod Biomed Online 2001; 4: 30-8.

3. Gardner DK and Lane M. Culture and selection of viable blastocysts: a feasible proposition for human IVF? Hum Repod Update 1997; 3 : 367-82. [CrossRef]

4. Pool TB. Recent advances in the production of viable human embryos in vitro: Reprod Biomed Online 2002; 4: 294-302. [CrossRef]

5. Biggers JD. Fundamentals of the design of culture media that support human preimplantation development. In: Van Blerkom $\mathrm{J}$, ed. Essential IVF. Norell, MA: Kluwer Academic Press 2003; 291-332.

6. Leese HJ. Formation and function of oviduct fluid. J Reprod Fertil 1988; 82: 843-56. [CrossRef]

7. Gardner DK, Lane M, Calderon I and Leeton J. Environment of the preimplantation human embryo in vivo: metabolite analysis of oviduct and uterine fluids and metabolism of cumulus cells. Fertil Steril 1996; 65: 349-53.

8. Gardner DK. Changes in requirements and utilization of nutrients during mammalian preimplantation embryo development and their significance in embryo culture. Theriogenology 1998; 49: 83-102. [CrossRef]

9. Freshney RI. Culture of animal cells. 4th ed. New York: Wiley-Liss, 2000.

10. Edwards RG. Test-tube babies. Nature 1981; 293: 253-6. [CrossRef]

11. Edwards RG, Purdy JM, Steptoe PC et al. The growth of human preimplantation embryos in vitro. Am $\mathrm{J}$ of Obstet and Gynecol 1981; 141: 408-16 
12. Menezo Y, Testart J, Perone D. Serum is not necessary in human in vitro fertilization and embryo development. Fertil Steril 1984; 42: 750-5. [CrossRef]

13. Quinn P, Kerin JF, Warnes GM. Improved pregnancy rate in human in vitro fertilization with the use of a medium based on the composition of human tubal fluid. Fertil Steril 1985; 44: 493-8.

14. Barnet DK, Bavister BD. What is the relationship between the metabolism of preimplantation embryos and their developmental competence? Molecular Reproduction and Development 1996; 43: 378-83.

15. Gardner DK and Lane M. Embryo culture systems. In Trouson AO, Gardner DK (eds) Handbook of in Vitro Fertilization, 2nd edn. 1999 CRC Press, Boca Raton pp. 205-64.

16. Leese HJ and Barton AM. Production of pyruvate by isolated mouse cumulus cells. J Exp Zool 1985; 234: 231-6. [CrossRef]

17. Quinn P. Enhanced results in mouse and human embryo culture using a modified human tubal fluid medium lacking glucose and inorganic phosphate. J Assist Reprod Genet 1995; 12: 97-105. [CrossRef]

18. Pool TB, Atiee SH and Martin JE. Oocyte and embryo culture: basic concepts and recent advances. Infertil Reprod Med Clin N Am 1998; 9: 181-203.

19. Barnes FL, Crombie A, Gardner DK, Kausche A, Lacham-Kaplan O, Suikkari AM, et al. Blastocyst development and pregnancy after in vitro maturation of human primary oocytes, intracytoplasmic sperm injection and assisted hatching. Hum Repod 1995; 10: 3243-7.

20. Lawitt JA and Biggers JD. Optimizing of mouse embryo culture media using simplex methods. J Reprod Fert 1991; 91: 543-56.

21. Lawitt JA and Biggers JD. Joint effects of sodium chloride, glutamine, and glucose in mouse preimplantation embryo culture media. Molecular Reproduction and Development 1992; 31: 189-94.

22. Biggers JD. Reflections on the culture of the preimplantation embryo. International Journal of Developmental Biology 1998; 42: 879-84.

23. Summers MC, Biggers JD. Chemically defined media and the culture of mammalian preimplantation embryos: historical perspective and current issues. Hum Reprod Update 2003; 9: 557-82. [CrossRef]

24. Biggers JD and Summers MC. Choosing a culture medium: making informed choices. Fertil Steril 2008; 90: 473-83. [CrossRef]

25. Whitten WK. Culture of tubal ova. Nature 1956; 177: 96. [CrossRef]

26. Brinster RL. IV. The effect of interaction of energy sources. J Reprod Fertil 1965; 10: 227-40.

27. Leese HJ. Metabolism of the preimplantation mammalian embryo. Oxf Rev Reprod Biol 1991; 13: 35-72.

28. Rieger D. Relationship between energy metabolism and development of the early embryo. Theriogenology 1992; 37: 75-93. [CrossRef]

29. Bavister BD. Culture of preimplantation embryos: facts and artefacts. Hum Reprod Update 1995; 1: 91-148. [CrossRef]

30. Bavister BD. Glucose and the culture of human embryos. Fertil Steril 1999; 72: 233-4. [CrossRef]

31. Leese HJ and Barton AM. Pyruvate and glucose uptake by mouse ova and preimplantation embryos. J Reprod Fertil 1984; 72: 9-13. [CrossRef]

32. Leese HJ, Biggers JD, Mroz EA and Lechene C. Nucleotides in a single mammalian ovum or preimplantation embryo. Anal Biochem 1984; 140: 443-8. [CrossRef]

33. Leese HJ, Conaghan J, Martin KL and Hardy K. Early human embryo metabolism. BioEssays 1993; 15: 259-64. [CrossRef]

34. Reitzer LJ, Wice BM, Kennell D. The pentose cycle; control and essential fuction in HeLa cell nucleic acid synthesis. J Biol Chem 1980; 255: 5616-26.

35. Biggers JD. McGinnis LK, Raffin M. Amino acids and preimplantation development of the mouse in protein-free potassium simplex optimized medium: Biol Reprod 2000; 63: 281-93. [CrossRef]

36. Crosby IM, Gandolf F and Moor FM. Control of protein synthesis during early cleavage of sheep embryos. J Reprod Fertil 1988; 82: 769-75. [CrossRef]
37. Van Winkel LJ, Haghighat N and Campione AL. Glycine protects preimplantation mouse conceptuses from a detrimental effect on development of the inorganic ions in oviductal fluid. J Exp Zool 1990; 253: 215-9.

38. Edwards LE, Williams DA and Gardner DK. Intracellular pH of the mouse preimplantation embryo: amino acids act as buffers of intracellular pH. Hum Reprod 1998; 13: 3441-8. [CrossRef]

39. Liu Z and Foot RH. Development of bovine embryos in KSMO with added superoxide dismutase and taurine and with five and twenty percent O2. Biol Reprod 1995; 56: 786-90. [CrossRef]

40. Lindenbaum A. A survey of natural occurring chelating ligands. Adv Exp Med Biol 1973; 40: 67-77. [CrossRef]

41. Gardner DK and Lane M. Amino acids and ammonium regulate the development of mouse embryos in culture. Biol Reprod 1993; 48: 377-85. [CrossRef]

42. Lane M and Gardner DK. Increase in postimplantation development of cultured mouse embryos by amino acids and induction of fetal retardation and exencephaly by ammonium ions. J Reprod Fertil 1994; 102: 305-12. [CrossRef]

43. Lane M, Gardner DK. Non-essential amino acids and glutamine decrease the time of the first three cleavage divisions and increase compaction of mouse zygotes in vitro. J Assist Reprod Genet 1997; 14: 398-403. [CrossRef]

44. Lane M, Gardner DK. Differential regulation of mouse embryo developments and viability by amino acids. J Reprod Fertil 1997; 109: 153-64. [CrossRef]

45. Leese HJ. Quiet please, do not disturb: a hypothesis of embryo metabolism and viability. BioEssays 2002; 24: 845-9. [CrossRef]

46. Leese HJ, Sturmey RG, Baumann CG, McEvoy TG. What does an embryo need? Hum Fertil 2003; 6: 180-5.

47. Leese HJ, Sturmey RG, Baumann CG, McEvoy TG. Embryo viability and metabolism: obeying the quiet rules. Hum Reprod 2007; 22 3047-50. [CrossRef]

48. Gardner DK and Lane M. The 2-cell block in CF1 mouse embryos is associated with an increase in glycolysis and a decrease in tricarboxylic acid (TCA) cycle activity: alleviation of the 2-cell block is associated with the restoration of in vivo metabolic pathway activities. Biol Reprod 1993; 49: suppl: 152.

49. Winitz M. Chemistry of the Amino Acids, Volume 3. John Wiley and Sons, Inc. New York 1961; 1929-54.

50. Cassuto G, Chavrier M, Menezo Y. Culture conditions and not prolonged culture time are responsible for monozygotic twinning in human in vitro fertilization. Fertil Steril 2003; 80: 462-3. [CrossRef]

51. Abramczuk J, Solter D and Koprowski H. The beneficial effect of EDTA on development of mouse one-cell embryos in chemically defined medium. Dev Biol 1977; 61: 378-83. [CrossRef]

52. Gardner DK, Lane MW and Lane M. Bovine blastocyst cell number is increased by culture with EDTA for the first $72 \mathrm{~h}$ of development from the zygote. Theriogenology 1997; 47: 278. [CrossRef]

53. Biggers JD, McGinnis LK and Lawitts JA. One-step versus two-step culture of mouse preimplantation embryos: is there a difference? Hum Reprod 2005; 20: 3376-84. [CrossRef]

54. McManus ML, Churchwell KB, and Strange K. Regulation of Cel Volume in Health and Disease. N Engl J Med 1995; 333: 1260-6.

55. Borland RM, Biggers JD, Lechene CP and Tymor ML. Elemental composition of fluid in the human Fallopian tube. J Reprod Fertil 1980; 58: 479-82. [CrossRef]

56. Biggers JD, Lawitts JA and Lechene CP. The protective action of betaine on the deleterious effects of $\mathrm{NaCl}$ on preimplantation mouse embryos in vitro. Mol Reprod Dev 1993; 34: 380-90. [CrossRef]

57. Ho Y, Wiggelswoth K, Eppig IJ and Schultz RM. Preimplantation development of mouse embryos in KSOM: augmentation by amino acids and anlaysis of gene expression. Mol Reprod Dev 1995; 41: 232-8. [CrossRef] 
58. Pool T. Optimizing pH in clinical embryology. Clin Embryol 2004; 7: 1-17.

59. Swain JE. Optimizing the culture environment in the IVF laboratory: impact of $\mathrm{pH}$ and buffer capacity on gamete and embryo quality. Reprod Biomed Online 2010; 21: 6-16. [CrossRef]

60. Bavister BD and McKiernan SH. Regulation of hamster embryo development in vitro by amino acids. In Bavister, BD (ed.), Preimplantation Embryo Development. Springer Verlag, New York 1993; 57-72.

61. Phillips KP, Leveille MC, Claman P and Baltz J. Intracellular $\mathrm{pH}$ regulation in human preimplantation embryos. Hum Reprod 2000; 15: 896-904. [CrossRef]

62. Edwards LJ, Williams DA, Gardner DK. Intracellular $\mathrm{pH}$ of the preimplantation mouse embryo: effects of extracellular $\mathrm{pH}$ and weak acids. Mol Rerpdo Dev 1998b; 50: 434-42. [CrossRef]

63. Good NE, Winget GD, Winter W, Connolly TN, Izawa S, and Singh RM. Hydrogen ion buffers for biological research. Biochemistry 1966; 5: 467-77. [CrossRef]

64. Iwasaki T, Kimura E, Totsukawa K. Studies on a chemically defined medium for in vitro culture of in vitro matured and fertilized porcine oocytes. Theriogenology 1999; 51: 709-20. [CrossRef]

65. Swain JE and Pool T. Supplementation of sequential embryo culture medium with synthetic organic buffers supports development of mouse embryos in an elevated CO2 environment. Reprod Biomed Online 2009; 16.

66. Mash HE, Chin YP, Sigg L, Hari R, Xue H. Complexation of copper by zwitterionic aminosulfonic (good) buffers. Anal Chem 2003; 75: 671-7. [CrossRef]

67. Stellwagen NC, Bossi A, Gelfi C and Righetti PG. DNA and buffers: are there any noninteracting, neutral $\mathrm{pH}$ buffers? Anal Biochem 2000; 287: 167-75. [CrossRef]

68. Gardner DK. Development of serum-free media for the culture and transfer of human blastocysts. Hum Reprod 1998; 13: 218-25.

69. Campbell S, Swann HR, Aplin JD, Seif MW, Kimber SJ and Elstein M. CD44 is expressed throughout pre-implantation human embryo development. Hum Reprod 1995; 10: 425-30. [CrossRef]

70. Gardner DK, Lane M, and Rodriguez-Martinez H. Fetal development after transfer is increased by replacing protein with the glycoaminoglycan hyaluronate for embryo culture. HR update 1997. p. 380

71. Valojerdi MR, Karimian L, Yazid PE, Gilani MAS, Madani T and Baghestani AR. Efficacy of a human embryo transfer medium: a prospective, randomized clinical trial study. J Assist Reprod Genet 2006; 23: 207-12. [CrossRef]

72. Lane M and Gardner DK. Embryo culture medium: which is the best? Best Practice \& Reserch Clin Obstet and Gynaecology 1997; 21: 83-100.

73. Wang X, Falcone T, Attaran M, Goldberg JM, Agarwal A, Sharma RK. Vitamin $\mathrm{C}$ and vitamin E supplemaentation reduce oxidative stressinduced embryo toxicity and improve the blastocyst development rate. Fertil Steril 2002; 78: 1272-7. [CrossRef]

74. Bulgurcuoglu S, Özsait B and Attar E. Büyüme Faktörlerinin Oosit ve Embriyo Gelisimi Üzerindeki Etkisi. Artemis 2003; 4: 18-26.
75. Richter KS. The importance of growth factors for preimplantation embryo development and in-vitro culture. Curr Opin Obstet Gynecol 2008; 20: 292-304.

76. Lemeire $\mathrm{K}$, Van Merris $\mathrm{V}$ and Cortvrindt $\mathrm{R}$. The antibiotic streptomycin assessed in a battery of in vitro tests for reproductive toxicology. Toxicol In Vitro 2007; 21: 1348-53. [CrossRef]

77. Cook S, Quinn P, Kime L, Ayres C, Tyler JPP and Driscoll GL. Improvement in early human embryo development using new formulation sequential stage-specific culture media. Fertil Steril 2002; 78: 1254-60.

78. Aoki VW, Wilcox AL, Peterson CM, Parker-Jones K, Hatasaka HH, Gibson M, et al. Comparison of four media types during 3-day human IVF embryo culture. RBM Online 2005; 10: 600-6. [CrossRef]

79. Ebert P, Sypajlo B, Tomalak K and Völklein K. Prospective comparison of two commercially available culture media under the provisons of the German embryo protective law. J TurkishGerman Gynecol Assoc 2009; 10: 10-3.

80. Xella Susanna, Marsella T, Tagliasacchi D, Giulini S, La Marca A, Tirelli A, et al. Fertil Steril 2010; 93: 1859-63. [CrossRef]

81. Campo R, Binda MM, VanKerkhoven G, Frederickx V, Serneels A, Roziers P, et al. Critical reappraisal of embryo quality as a predictive parameter for pregnancy outcome: a pilot study. F, V \& V in ObGyn 2010; 2: 289-95.

82. Van Langendonckt A, Demylle D, Wyns C, Nisolle M, Donnez J. Comparison of G1.2/G2.2 and Sydney IVF cleavage/blastocyst sequential media for the culture of human embryos: a prospective, randomized, comparative study. Fertil Steril 2001; 76: 1023-31. [CrossRef]

83. Reed ML, Hamic A, Thompson DJ and Caperton CL. Continous uninterrupted single medium culture without medium renewal versus sequential media culture: a sibling embryo study. Fertil Steril 2009; 92: 1783-6. [CrossRef]

84. Paternot G, Debrock S, D'Hooghe TM and Spiessens C. Early embryo development in a sequential versus single medium: a randomized study. Rerpod Biology and Endocrinology 2010; 8: 83. [CrossRef]

85. Biggers JD and Racowsky C. The development of fertilized human ova to the blastocyst stage in KSOMAA medium: is a two-step protocol necessary? RBM Online 2002; 5: 133-40. [CrossRef]

86. Sepulveda S, Garcia J, Arriaga E, Diaz J, Noriega-Portella L and Noriega-Hoces L. In vitro development and pregnancy outcomes for human embryos cultured in either a single medium or in a sequential media system. Fertil Steril 2009; 91: 1765-70.

87. Perin PM, Maluf M, Nicolosi Foltran Januário DA, Nascimento Saldiva $\mathrm{PH}$. Comparison of the efficacy of two commercially available media for culturing one-cell embryos in the in vitro fertilization mouse model. Fertil Steril 2008; 90 Suppl 2; 1503-10. [CrossRef]

88. Hentemann $M$ and Bertheussen $K$. New media for culture to blastocyst. Fertil Steril 2009; 91: 878-83. [CrossRef]

89. Rivera RM, Stein P, Weaver JR, Mager J, Schultz RM and Bartolomei MS. Manipulation of mouse embryos prior to implantation result in aberrant expression of imprinted genes on day 9.5 of development. Hum Mol Genet 2008; 17: 1-14. 